\title{
ERADICATION OF PRRS FROM BACKYARD SWINE HERDS IN HUNGARY BETWEEN 2012 AND 2018
}

\author{
Imre Nemes ${ }^{1}$, Tamás MOLNÁR ${ }^{1}$, Tamás ABONYI ${ }^{1}$, Zsolt TERJÉK $^{1}$, Ádám BÁLINT ${ }^{2 *}$ \\ and István SZABÓ ${ }^{1}$ \\ ${ }^{1}$ National PRRS Eradication Committee; ${ }^{2}$ Department of Virology, National Food Chain \\ Safety Office Veterinary Diagnostic Directorate, Tábornok u. 2, H-1134 Budapest, \\ Hungary
}

(Received 23 July 2019; accepted 18 September 2019)

In the EU Member States with a traditionally significant pig industry, the prevalence of PRRS infections is high. Therefore, the Pig Strategy of the Government of Hungary prioritises eradication of PRRSV in Hungary. For the first time among the EU Member States, a National PRRS Eradication Programme was introduced in order to reach a more efficient, economical and competitive international market position. Although its significance has decreased in recent decades, $20 \%$ of the Hungarian pig population is still kept on small-scale (backyard) farms $(<100$ animals). The prevalence of PRRSV in backyard farms was $3.9 \%$ at the beginning of the programme. The present paper details the measures applied during the different phases of the programme in backyard farms. During all the phases, serological testing of the breeding animals of the registered small-scale herds was performed, including the highest number of individual animals. Seropositive individuals were tested by PCR and were removed from the backyard farm within the framework of official measures. By sequencing the identified PRRS strains, the possible epidemic relationships between small-scale and large-scale farms were continuously monitored. As a result of the programme, PRRS-free status of the small-scale herds was achieved by the end of 2015 , and this status was maintained in 2016-2018.

Key words: PRRS, eradication, small-scale swine herds, backyard pigs

In 1895, 3.2 million pigs were kept in the present territory of Hungary. This number decreased to 1.1 million after the Second World War. By 1974, it increased to 9.4 million, and the number of piglets peaked with 11 million heads in 1983. In that year, 765,000 sows were kept in Hungary. The decline in the sector has accelerated sharply since the early 1990s. The number of sows fell from

*Corresponding author; E-mail: balintad@nebih.gov.hu; Phone: 0036 (30) 984-5102

Open Access. This is an open-access article distributed under the terms of the Creative Commons AttributionNonCommercial 4.0 International License (https://creativecommons.org/licenses/by-nc/4.0/), which permits unrestricted use, distribution, and reproduction in any medium for non-commercial purposes, provided the original author and source are credited, a link to the CC License is provided, and changes - if any - are indicated. 
624,000 in 1990 to 379,000 by the turn of the millennium. In $2018,178,000$ sows were kept in Hungary. The decline in headcount in recent decades can be attributed to social, livestock farming and product market changes.

Closer links between large and small pig farms, international integration, introduction of more sensitive hybrids and the often obsolete farming technology are the major reasons for the failure of internal epizootic control of several major infectious diseases (such as mycoplasmosis, E. coli diseases in piglets, actinobacillosis, atrophic rhinitis), for the occurrence of parvovirosis, streptococcosis, leptospirosis, Aujeszky's disease and recently for the cases of porcine reproductive and respiratory syndrome (PRRS) and porcine circovirus-related diseases.

In the Hungarian agricultural sector, despite the significant decrease in the number of animals in recent years, pork production remains to be of high importance. Successful implementation of PRRS eradication would greatly facilitate an increase in market opportunities following the eradication of Aujeszky's disease.

The characteristic feature of Hungarian pig breeding has been the coexistence of two different forms of farming for decades. For the large-scale pig farming business organisation (an undertaking engaged in agricultural activity without an individual enterprise, with its own budget and in association with other organisations) production serves the purpose of market sales.

In the case of individual farmers (sole proprietor or household engaged in agricultural activity regardless of livestock and land area) up to 1-2 breeding sows and few (4-10) fatteners are typical. In these courtyards (backyards), keeping pigs around the house is considered to be the means of recovery of plantderived waste from food processing, production, and especially home-made meat products for the winter season. The farming technology used in these herds is in most cases rather extensive. Many stocks are usually completely replaced during certain periods of the year, after meat processing (e.g. Christmas).

The definition of small-scale herds appeared first in the 41/1997 (V.28.) FM decree (Animal Health Regulation) as a livestock farm with less than 100 pigs (Anonymous, 1997).

During the preparation of the PRRS eradication programme, an average of 408 sows were held by domestic business organisations during the preparation of the PRRS eradication programme, while in the case of individual farmers, two sows were kept on average. The total number of pigs held by individual farmers was 156,345 , representing $29 \%$ of the total number of pigs in the country (Central Statistical Office, 2019).

Pigs kept on small-scale farms can also play an important role in the spread of epizootic infectious diseases. The special extensive keeping technology, applying the lowest cost of production and the failure to meet the stringent requirements for the production of 'quality' animal products are major threats to the epizootiological situation of the pig population in the country. 
During the successful eradication of Aujeszky's disease completed in 2006, the eradication was subsidised in the case of small-sized stocks (Szabó and Molnár, 2004).

In the pig herds in countries with traditionally significant intensive pig holdings, PRRS causes the biggest economic losses worldwide (Holtkamp et al., 2013; Valdes-Donoso et al., 2018; Scottish Agricultural Organisation Society Ltd., 2018). The estimated worldwide cost of this major pathogenic virus (PRRSV) is over $\$ 2$ billion a year. The most important factors in preventing the infection of individual herds are strict biosecurity measures, the adequately controlled transport of animals, the reduction of the number of animals imported, and the ban on imports.

The American Association of Swine Veterinarians (AASV) urged the Association to take the lead in the PRRS eradication process (Vansickle, 2015). In Europe, four countries (Norway, Sweden, Finland, and Switzerland) are PRRS free. There are local eradication programmes in Denmark and in The Netherlands (Rathkjen and Dall, 2017). A national PRRS eradication programme was launched in Scotland in 2018 (Scottish Agricultural Organisation Society Ltd., 2018).

The strategy for pigs of the Hungarian government (Anonymous, 2012) highlights the need to be free of PRRSV at country level. It sets out as a priority task to ensure the conditions for the veterinary programmes necessary for the successful operation of the pig sector, in particular the PRRS eradication programme, under the responsibility of the Minister for Rural Development. As part of this strategy, the National PRRS Eradication Programme, which is unique among the EU Member States, but also among the large pig-keeping countries in the world, has introduced a national programme for the first time that can help the Hungarian pig sector become an effective, profitable and competitive market player in the long term on the EU, the Russian and the Far Eastern pig market.

In this paper, we present the results of the PRRSV eradication programme launched in 2012 for pigs kept on backyard farms in Hungary.

\section{Materials and methods}

The legal background of the PRRS eradication programme is the $3 / 2014$ (I. 16.) VM decree, which was drafted following consultations with experts in the field of swine breeding and integration, as well as practitioners and scientists (Anonymous, 2014). The proposals of these experts are an integral part of the National Eradication Plan. On the basis of the decree, the European Union accepted the national PRRS eradication programme. Following this decree, the National PRRS Eradication Plan was revised from time to time.

The Plan regulates the measures against PRRS and defines the responsible executors of the programme. To facilitate the implementation of the professional, 
epidemiological, administrative or other issues arising from the process of eradication, a National PRRS Eradication Committee was appointed. The task of the Committee was to formulate and comment on professional measures regarding the eradication of PRRS, and to provide support for the decision-making process of the national authorities.

Preceding the official start of the programme, in 2012-2013, laboratory surveillance for PRRS ('Surveillance Phase') was carried out. Its purpose was to assess the extent of PRRS prevalence in small-scale stocks, followed by assessment of the potential risk of infection to large-scale swine farms.

In 2014 and 2015, based on laboratory tests, the small-scale pig herds were qualified for PRRS as specified by the 3/2014 (I. 16.) VM decree (Anonymous, 2014) ('Qualification-Eradication Phase'). The costs of the examinations were covered by the state. During that period, we attempted to investigate each breeding animal (breeding sows, replacement gilts, breeding boars) and, in some small herds, even fatteners about which the veterinary authority had data. Based on the test results, the farms were certified by the veterinary authority. In the case of seropositivity, the authority ordered the depopulation of the herds with state compensation, but without the need for repopulation.

From 2016, until the end of the national eradication programme, in the 'Control of Freedom Phase', according to Articles 7 (8) and (9) of the Decree (Anonymous, 2014), all breeding pigs were examined. The number of samples was set to be able to detect seropositivity with $95 \%$ confidence at $10 \%$ prevalence in non-eradicated areas and at $20 \%$ prevalence in eradicated ones. In the course of sampling our target was to investigate as many small-scale herds as we could.

The first test to detect antibodies to PRRS was an ELISA (Ingenasa, Spain) according to the recommendations of the manufacturer in all the three phases. Seropositivity was confirmed or ruled out by another serological test, indirect immunofluorescence (IIF) (Anonymous, 2015). In addition, the virotype PRRSV RT-PCR Kit (Qiagen, Germany) was applied for direct virus detection according to the manufacturer's instructions in the blood sample in question. At slaughter of the same animals, samples from their organs were also taken for virological (PCR) examination. In case of a positive PCR test, sequencing of the PRRSV ORF5 gene was also attempted. With the help of the data obtained, a phylogenetic analysis was performed to detect possible epidemiological relationships (Szabó et al., manuscript).

In the 'Qualification-Eradication and Control of Freedom Phases', if we found PRRS-positive individuals on a backyard farm of a settlement, the district veterinary authority with the consent of the county veterinary authority approved a plan for the eradication of the disease. In order to accelerate or complete the eradication process in a given settlement, the slaughter of breeding animals with state compensation was possible only with the permission of the Chief Veterinary Officer. Following the eradication of the disease, the farm was subjected to a stringent disinfection. 


\section{Results}

In 2012-2013, during the 'Surveillance Phase', pigs were kept in nearly $60 \%$ of the settlements in Hungary. Of the examined backyards, PRRS-seropositive individuals were found in nearly $4 \%$ in both years. Seropositivity was $4.7 \%$ in 2012 and $3.9 \%$ in 2013 (Tables 1 and 2). The proportion of tested breeding sows kept in small-scale herds among the total number of breeding sows was around 60\% in both 2012 and 2013 (Table 3). Despite the fact that at that time, in addition to breeding animals, in some cases other age groups were also examined, it can be safely stated that the high sampling rate was likely to be fairly representative of the PRRSV infection level of these farms.

In the second phase ('Qualification-Eradication phase'), in 2014, nearly all of the small-sized herds (92\%) were examined serologically for PRRS (Table 3). The qualification was completed in 2015 , when we surveyed $61 \%$ of the breeding sows.

In $20144.6 \%$, while in $20153.4 \%$ of the tested animals proved to be seropositive (Tables 4 and 5). These data include the mandatory confirmatory tests (IIF). According to Section 9 (4) of the Decree (Anonymous, 2014), seropositive animals were culled on the basis of an official procedure, so that on 31 December 2015 the PRRS-free status of small-scale of Hungarian swine herds was declared.

This free status was confirmed in the 2016, 2017 and 2018 monitoring programmes of PRRS carried out in small-scale swine populations. In all these three years, seropositivity was only around $1 \%$ (Table 6). Blood samples for the PRRS laboratory test from seropositive individuals were positive with two different serological methods (ELISA, IIF). In 2017 75\%, while in 2018 88\% of ELISA-positive serological tests for PRRS proved to be IIF positive. Seropositive pigs in 140-150 small-sized herds were slaughtered throughout the country.

In the studies, we attempted to confirm the presence of the virus by direct virological tests in individuals showing seropositivity. In 2017-2018, a total of 951 blood samples for PRRS were investigated by PRRS PCR test, and 40 $(4.2 \%)$ of them gave positive results. None of these PCR-positive samples originated from breeding sows. The PRRSV PCR positivity was observed in smallscale herds when irregular animal transport without veterinary certification was carried out or when infected nursery pigs were placed into small flocks for fattening purposes. This epizootiological connection was confirmed by the phylogenetic analysis. There was no infection that could have been traced back to using so-called 'hidden boars'. In 2017-2018, all out of the additional 26 cases were PRRSV PCR negative, when tonsil samples were collected at the slaughterhouse from earlier seropositive sows. 
NEMES et al.

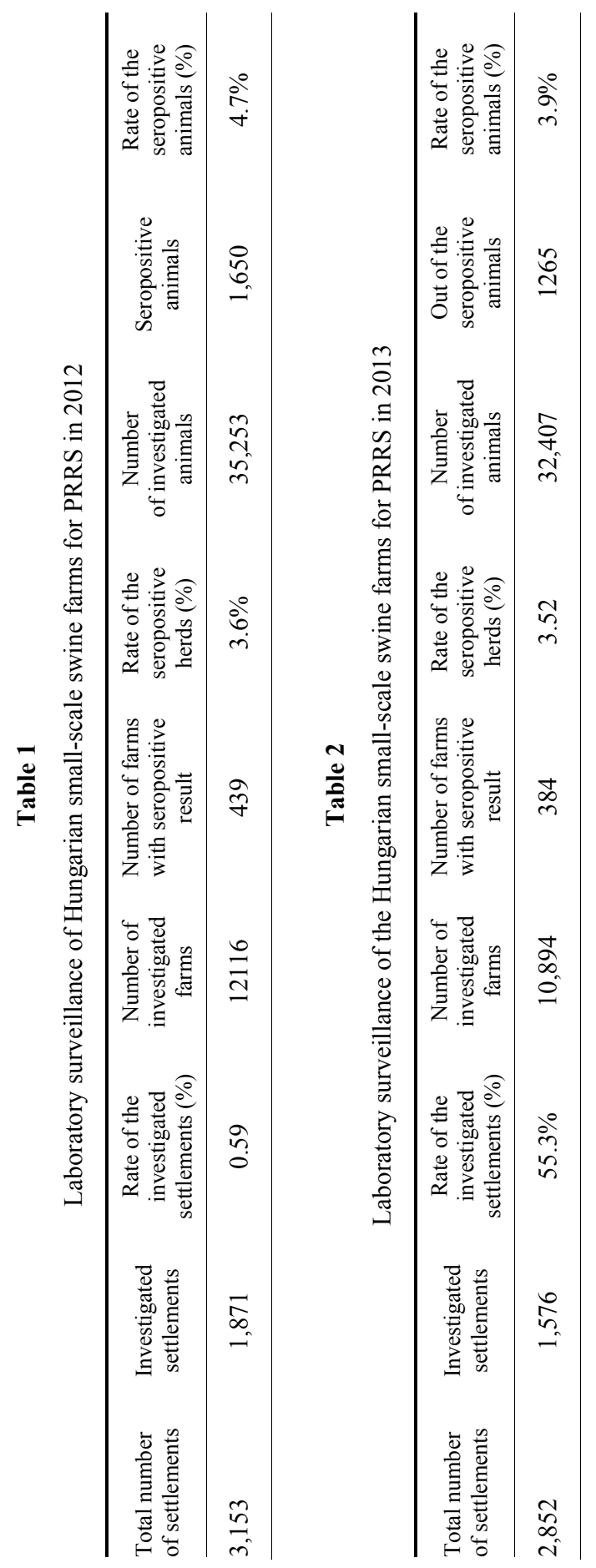


Table 3

Number of sows in individual farms and rate of their laboratory investigation for PRRS from 2012 to 2018

\begin{tabular}{cccc}
\hline Year & $\begin{array}{c}\text { PRRS } \\
\text { investigated animals }\end{array}$ & $\begin{array}{c}\text { Number } \\
\text { of sows kept } \\
\text { on individual farms }\end{array}$ & $\begin{array}{c}\text { Number } \\
\text { of investigated } \\
\text { animals/number } \\
\text { of breeding sows } \\
\text { at individual farms } \\
\text { in Hungary }\end{array}$ \\
\hline 2012 & 35,253 & 58,600 & $60.2 \%$ \\
2013 & 32,407 & 54,000 & $60.0 \%$ \\
2014 & 42,885 & 47,100 & $91.1 \%$ \\
2015 & 31,774 & 51,700 & $61.5 \%$ \\
2016 & 13,521 & 49,600 & $27.3 \%$ \\
2018 & 15,582 & 40,900 & $38.1 \%$ \\
\hline
\end{tabular}

Table 4

Laboratory surveillance of the Hungarian small-scale swine farms for PRRS in 2014

\begin{tabular}{lccccc}
\hline $\begin{array}{l}\text { Number of } \\
\text { investigated } \\
\text { farms }\end{array}$ & $\begin{array}{c}\text { Number of } \\
\text { farms with } \\
\text { seropositive } \\
\text { result }\end{array}$ & $\begin{array}{c}\text { Rate of } \\
\text { seropositive } \\
\text { herds (\%) }\end{array}$ & $\begin{array}{c}\text { Number of } \\
\text { investigated } \\
\text { animals }\end{array}$ & $\begin{array}{c}\text { Number of } \\
\text { seropositive } \\
\text { animals }\end{array}$ & $\begin{array}{c}\text { Rate } \\
\text { of the seropositive } \\
\text { animals } \\
(\%)\end{array}$ \\
\hline 42,885 & 1,959 & $4.6 \%$ & 11,524 & 437 & $3.79 \%$ \\
\hline
\end{tabular}

Table 5

Laboratory surveillance of the Hungarian small-scale swine farms for PRRS in 2015

\begin{tabular}{lccccc}
\hline $\begin{array}{l}\text { Number of } \\
\text { investigated } \\
\text { farms }\end{array}$ & $\begin{array}{c}\text { Number of } \\
\text { farms with } \\
\text { seropositive } \\
\text { result }\end{array}$ & $\begin{array}{c}\text { Rate of } \\
\text { seropositive } \\
\text { herds (\%) }\end{array}$ & $\begin{array}{c}\text { Number of } \\
\text { investigated } \\
\text { animals }\end{array}$ & $\begin{array}{c}\text { Number of } \\
\text { seropositive } \\
\text { animals }\end{array}$ & $\begin{array}{c}\text { Rate } \\
\text { of the seropositive } \\
\text { animals } \\
(\%)\end{array}$ \\
\hline 31,744 & 1,082 & $3.4 \%$ & 6,970 & 302 & $4.33 \%$ \\
\hline
\end{tabular}

\section{Table 6}

Control of PRRS-free status: monitoring investigation of breeding animals on small-scale swine farms

\begin{tabular}{lccccccc}
\hline \multicolumn{2}{c}{2016} & & \multicolumn{2}{c}{2017} & & \multicolumn{2}{c}{2018} \\
\cline { 1 - 3 } \cline { 7 - 8 } $\begin{array}{l}\text { Total number of } \\
\text { investigations }\end{array}$ & $\begin{array}{c}\text { Seropositive } \\
\text { samples }\end{array}$ & & $\%$ & $\begin{array}{c}\text { Total number of } \\
\text { investigations }\end{array}$ & & $\begin{array}{c}\text { Seropositive } \\
\text { samples }\end{array}$ & $\%$ \\
\hline 13,521 & 139 & & $1.03 \%$ & 15,582 & & 150 & $0.96 \%$ \\
\hline
\end{tabular}




\section{Discussion}

Eradication of PRRS from swine herds is a good opportunity for the Hungarian swine industry to improve its market position. The swine population of Hungary became free from Aujeszky's disease in 2006 but in the meantime, PRRS, a new infectious pig disease that has caused the most severe economic losses worldwide, has also appeared in Europe.

The leaders of Hungarian agriculture correctly set the goals of eradication of this disease: eradicating PRRS virus from the swine population of Hungary, mitigating all kinds of economic damage, including indirect damage, reducing the use of antibiotics in the Hungarian pig sector, and long-term sustainable growth with international competitiveness (Anonymous, 2017).

Some experts highlighted the difficulties of the eradication programme, saying that PRRS eradication under small-scale stock circumstances cannot be executed. In their opinion, the present situation including the low biosecurity level of small-scale stocks, the discipline of farmers and the resistance of farmers to all forms of registration coupled with the declining prestige of the work of the veterinary authority and the range of uncertainties caused by its reorganisation represented too high risks in the case of these farms, which are playing a significant role in the spread of epizootics otherwise.

Uncontrolled or not fully registered animal movements pose a threat to the small-scale farms located close to the infected ones, but on the other hand the employees working at large-scale farms and keeping pigs around their house (as small-scale stock) pose a significant threat to all Hungarian swine herds as well.

Other experts stressed that the eradication of Aujeszky's disease proved that the infections of small herds do not pose a threat to large-scale pig farms, and on the other hand the spread of the pathogenic virus and the disease from animal to animal is slower (due to the significantly lower number of swine) than in the case of concentrated livestock farms (Pallaghy and Szabó, 2001).

In this paper, we presented the eradication of PRRS from the small pig farms in Hungary in three phases, 'Surveillance, Qualification-Eradication and Control'. During all the phases, we tried to carry out laboratory testing of the breeding animals of the registered small-scale herds with the highest number of individuals. In 'Qualification-Eradication Phase', seropositive individuals were removed from the backyard farms within the framework of official measures. We continuously monitored possible epizootiological relationships between smallscale and small- and large-scale farms. In the case of seropositive samples, we tried to detect, identify and characterise the virus by virological examination of the organs (lymph nodes, lung, spleen) of the slaughtered individuals.

The results of our investigations confirmed our opinion held already at the beginning of the eradication: 
(a) Small-scale herds, even without complying with the methods applied during the eradication, do not pose a serious threat to the PRRS status of largescale farms; quite the contrary, the infection of small-scale stocks often originated from PRRS-infected large-scale breeding or fattening herds.

(b) For the eradication of the disease from small-scale herds, the use of immunisation is not required, since the relatively low number of animals is a sufficiently restrictive force in the spread of the virus, and the infection ceases without any intervention.

(c) Monitoring examinations in small-scale herds are required from year to year, and the application of state veterinary measures corresponding to the results is required until the entire pig population in Hungary becomes free.

(d) In the case of small-scale herds, it is of the mutual interest and responsibility of the animal keeper, the attending veterinarian and the veterinary authority to achieve and maintain the infection-free status.

On the basis of our results obtained in the past five years, it can be concluded that PRRS eradication of the pig population kept on small-scale farms in Hungary was successfully carried out. The control of disease-free status, taking into account the results of 2016, 2017 and 2018, will be carried out annually as described in the PRRS decree, and the results will be evaluated regularly.

\section{References}

Anonymous (1997): Decree No. 41/1997 (V. 28.) of the Minister of Agriculture on issuing the Animal Health Regulation [in Hungarian].

Anonymous (2012): Decision No. 1323/2012 (VIII. 30.) of the Hungarian Government on the strategy of the swine industry in Hungary [in Hungarian]. Magyar Közlöny (Hungarian Gazette) 114, 19447.

Anonymous (2014): Decree No. 3/2014 (I. 16.) VM of the Minister of Rural Development on PRRS eradication of the swine population of Hungary [in Hungarian]. Magyar Közlöny (Hungarian Gazette) 3, 447.

Anonymous (2015): Porcine Reproductive and Respiratory Syndrome. Detection of antibodies with the indirect immunofluorescence assay. OIE Manual of Diagnostic Test and Vaccines for Terrestrial Animals, 2015. Chapter 3.8.6.B.2.2.

Anonymous (2017): Decision No. 7/2017 of the Chief Veterinary Officer of Hungary. Földmüvelésügyi Értesítő (Agricultural Reports) volume LXVII, number 12, 555.

Central Statistical Office of Hungary (2019): Infraannual data of Agriculture. (http://www.ksh.hu/ stadat_evkozi 4 1)

Holtkamp, D. J., Kliebenstein, J. B., Neumann, E. J., Zimmerman, J. J., Rotto, H. F., Yoder, T. K., Wang, C., Yeske, P. E., Mowrer, C. L. and Haley, C. A. (2013): Assessment of the economic impact of porcine reproductive and respiratory syndrome virus on United States pork producers. J. Swine Health Prod. 21, 72-84.

Pallaghy, Á. and Szabó, I. (2001): Experiences with the eradication of Aujeszky's disease from small pig herds in Devavanya, Bekes county, Hungary 1998-2000. The Pig J. 47, 13-22.

Rathkjen, P. H. and Dall, J. (2017): Control and eradication of porcine reproductive and respiratory syndrome virus type 2 using a modified live type 2 vaccine in combination with a load, close, homogenise model: an area elimination study. Acta Vet. Scand. 59, 4. 
Scottish Agricultural Organisation Society Ltd. (2018): Scottish Porcine Reproductive and Respiratory Syndrome Elimination Project. http://www.saossupplychains.scot/scottish-prrs-eliminationproject/

Szabó, I. and Molnár, T. (2004): Eradication of Aujeszky's disease in Hungary between 1998 and 2000. Magy. Allatorvosok 126, 80-86.

Szabó, P. M., Szalay, D., Kecskeméti, S., Molnár, T., Szabó, I. and Bálint, Á. (2019): Investigations on spreading of PRRSV among swine herds by bioinformatics methods. Manuscript.

Valdes-Donoso, P., Alvarez, J., Jarvis, L. S., Morrison, R. B. and Perez, A. M. (2018): Production losses from an endemic animal disease: Porcine Reproductive and Respiratory Syndrome (PRRS) in selected Midwest US sow farms. Front. Vet. Sci. 5, 102.

Vansickle, J. (2015): PRRS elimination final goal. Position statement of the board of directors of the American Association of Swine Veterinarians (AASV). https://www.nationalhogfarmer. com/mag/farming_prrs_elimination_final

This is an open-access article distributed under the terms of the Creative Commons Attribution 4.0 International License (https://creativecommons.org/licenses/by/4.0/), which permits unrestricted use, distribution, and reproduction in any medium, provided the original author and source are credited, a link to the CC License is provided, and changes - if any - are indicated. (SID_1) 